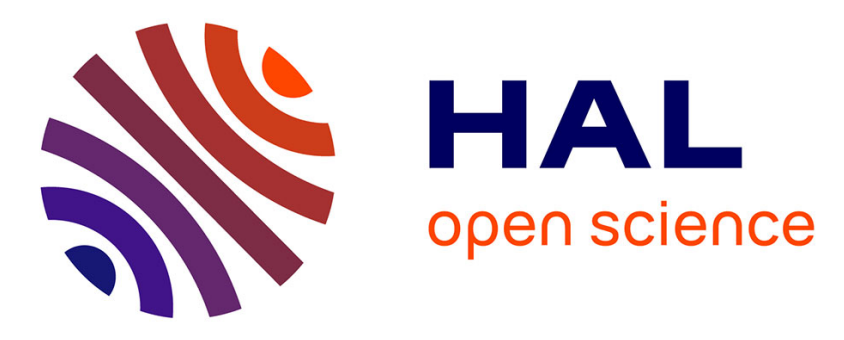

\title{
Medieval Endowment Cultures in Western India: Buddhist and Muslim Encounters - Some Preliminary Observations
}

\author{
Annette Schmiedchen
}

\section{- To cite this version:}

Annette Schmiedchen. Medieval Endowment Cultures in Western India: Buddhist and Muslim Encounters - Some Preliminary Observations. Blain Auer; Ingo Strauch. Encountering Buddhism and Islam in Premodern Central and South Asia, 9, De Gruyter, pp.203-218, 2019, Mondes de l'Asie du Sud et de l'Asie Centrale, 978-3-11-062916-3. 10.1515/9783110631685-009 . hal-03012318

\author{
HAL Id: hal-03012318 \\ https://hal.science/hal-03012318
}

Submitted on 23 Nov 2020

HAL is a multi-disciplinary open access archive for the deposit and dissemination of scientific research documents, whether they are published or not. The documents may come from teaching and research institutions in France or abroad, or from public or private research centers.
L'archive ouverte pluridisciplinaire HAL, est destinée au dépôt et à la diffusion de documents scientifiques de niveau recherche, publiés ou non, émanant des établissements d'enseignement et de recherche français ou étrangers, des laboratoires publics ou privés.

\section{(ㅇ)(1) $\$$}

Distributed under a Creative Commons Attribution - NonCommercial - NoDerivatives 44.0 


\title{
Medieval Endowment Cultures in Western India: Buddhist and Muslim Encounters - Some Preliminary Observations
}

\begin{abstract}
Endowment cultures based on Buddhist, Hindu-Brahmanical, and Jain traditions flourished in pre-Islamic India. The donative practices influenced each other, and the extant records testify to a consensus among the followers of different religions with regard to the merit drawn from pious grants. Several rulers of the Maitraka dynasty were patrons of a Buddhist endowment culture in sixth to seventh-century Kathiawar. After the eighth century, patronage in favor of Buddhist monasteries apparently declined in Gujarat and Maharashtra. However, this decrease does not seem to have been caused by the first, short-term Muslim inroads into the region in the early eighth century, as the Hindu-Brahmanical endowment culture continued to prosper. On the contrary, there is epigraphic evidence that Muslim nobles, in their capacity as vassals of the indigenous Rāștrakūta rulers, made religious grants on the west coast in the tenth century, following the pattern set by the native kings. According to Arab sources, the first mosques were also built on the Konkan coast in the tenth century. With the dissemination of Islamic rule in northern India in the thirteenth century, Muslim rulers seem to have confiscated land and other resources that had been bestowed on monasteries and temples, probably with the aim of increasing state revenues and of patronizing the institution of Islamic endowments (waqf).
\end{abstract}

Keywords: Western India, Maitraka, Rāșțrakūṭa, endowments, inscriptions

In this paper, I focus on Buddhist and Muslim encounters in the western part of the subcontinent, where, for geographical reasons, we might expect some of the earliest evidence for interaction and exchange between Muslim and indigenous Indian communities. The region came to prominence with the expansion of Arab armies into Sind (in southeast present-day Pakistan) in the early eighth century. I address the subject of endowment cultures for several reasons: The source material for early medieval endowment practices is particularly abundant. Medieval endowments have strong religious connotations and, at the same time, are a complex phenomenon that touches "on all areas of a society: religion and politics, social structures, the economy and welfare, art, gender or 
regional development." ${ }^{11}$ Although I emphasize Buddhist and Muslim encounters, at least one other party, that is, Brahmins, and perhaps other groups (for example, Jains), were long involved in South Asian contexts. In India, interreligious activities are much older than the encounter between Buddhism and Islam, and mutual religious influences were especially important in the field of gift giving and endowments.

Flourishing endowment cultures based on Buddhist, Hindu-Brahmanical, and Jain traditions of gift giving $(d \bar{a} n a)^{2}$ existed in pre-Islamic India. For clarification, we should add: The term 'endowment' (Stiftung in German) denotes a permanent donation of non-transferable wealth. The revenues of the wealth were dedicated to serve specific long-lasting religious and charitable purposes in contrast to a gift in a more general sense. ${ }^{3}$ Although there was no exact equivalent for the term 'endowment' in premodern India, the concept of pious grants that were intended for eternity did exist. Stone and metal were the most important media on which to inscribe endowments in pre-Islamic India, and vast numbers of such title deeds are extant from late antiquity and the medieval period. Thousands of documents engraved on copper plates registered royal grants of land or whole villages to religious recipients. The majority of the early medieval donations supported Brahmins; but Buddhist monasteries, Hindu temples, and Jain institutions benefited from this practice as well. Competition among various potential recipients, either individuals or institutions, for patronage by royal figures and other elites was probably keen.

The expectations of donees of different denominations were not necessarily the same. This is evident in the specific wording of Buddhist, Brahmanical, and Hindu grants, ${ }^{4}$ which were made to last "as long as the moon and the sun, the oceans and the earth, rivers and mountains exist." "Various expressions were used for such endowments, for example, dharmadeya or dharmadāya for 'religious gifts' in a more general way, brahmadeya or brahmadāya for 'gifts to Brahmins,' and devadāya or devadāna, for 'gifts to gods. ${ }^{6}$ Despite these

1 Borgolte 2014: 14.

2 See, e.g., Heim 2004.

3 Or, as Leslie Orr (2011: 151) states, "Within the vast and extremely important category of the gift, we may distinguish gifts of a particular type, for which the English word 'endowment' is a convenient label. An endowment is a gift where the transfer of property is accompanied by the expectation that the gift will be able to provide permanent and ongoing support to its recipient or for the gift's intended purpose."

4 For Buddhist influence on the wording of endowment deeds, see von Hinüber 2013: 376.

5 Ācandrārkārṇavakșitisaritparvatasamakālīna. See e.g., Schmiedchen 2014: 143.

6 Sircar 1966: 60-61, 87-88, 92. Other terms focus less on the differences of the recipients, as e.g., agrahāra/agrāhāra or akșayanīin̄; see Sircar 1966: 10-11, 15. 
differences, the common, trans-religious goal of all those donations was to gain religious merit (punya). Pre-Islamic endowment traditions influenced each other; the extant epigraphs are evidence that there was a kind of consensus among the followers of the various beliefs regarding the merit of pious grants. ${ }^{7}$ Future kings were requested to preserve existing donations. In Brahmanical, Hindu, and Buddhist royal endowments we find stanzas like:

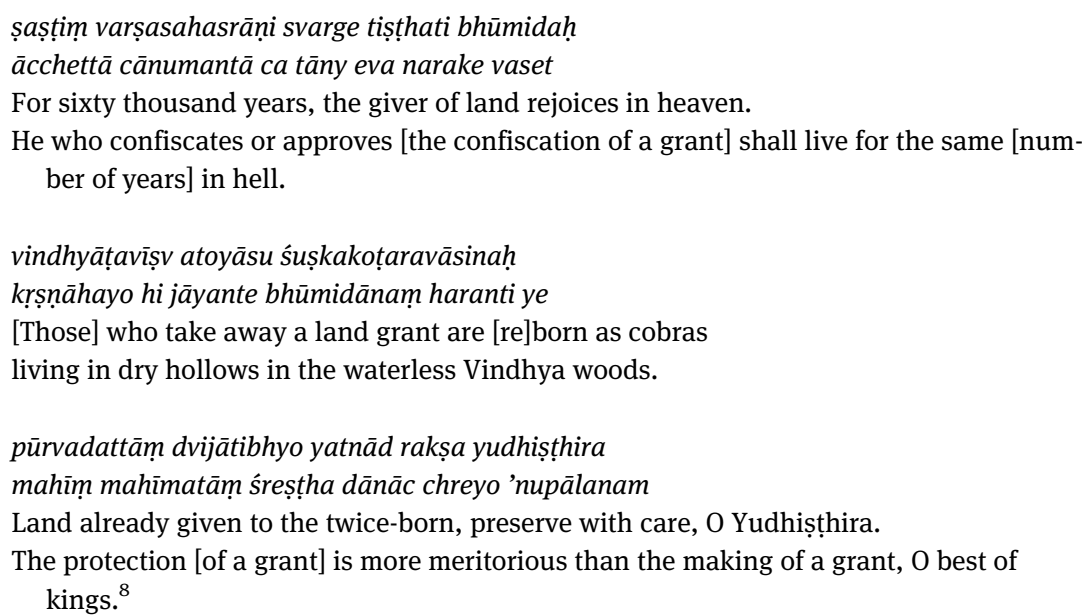

These stanzas were also popular under the kings of the Maitraka dynasty of Valabhī, who ruled over the peninsula of Kathiawar from the fifth to the eighth centuries. Seventy percent of their known corpus, that is, the majority of the more than one hundred extant Maitraka copper plate charters, are (like those of other contemporary royal lines) grants to Brahmins and unrelated to temples. Most donations were bestowed on individual recipients, only a few were for larger groups of Brahmins. ${ }^{9}$ But the Maitraka rulers also patronized a Buddhist endowment culture. One-quarter of their epigraphs recorded grants in favor of Buddhist institutions. Twenty-six Buddhist donations are extant, and among the donees were monasteries for monks (bhikșuvihāra), nunneries (bhikșuṇivihāra),

7 The strongest modification of this concept is perhaps related to the different approach of Mahāyāna Buddhism toward the concept of the transfer of punya. 'All beings' (sarvasattva) should benefit from religious merit accumulated by individuals or groups; Schopen 1997 [1985]: 39.

8 Pargiter 1912: 249-251; Kane 1941: 862, 1271-1277; Sircar 1966: 170-201; Schmiedchen 2014: 157.

9 For the Brahmanical endowments in general, see Shastri 2000: 417-452; for a group of fortyfour Brahmanical recipients, see Bhadkamkar 1911-12. 
and a few Mahāyāna institutions (a mahāyānikavihāra and a Tārā shrine). ${ }^{10}$ The Buddhist endowments of the Maitrakas were second in number after the Brahmanical ones and were much more numerous than those to Hindu temples. There are only five inscriptions for grants to Hindu deities: one for Mahādeva (Śiva), two for the sun god, and two for female goddesses. ${ }^{11}$

Buddhist (Mahāyāna) textual influence can be found in three Buddhist (non-Mahāyāna) Maitraka charters dating from the second half of the sixth century $^{12}$, i.e., a stanza from Āryaśūra's Jātakamālā,,$^{13}$ sometimes in a slightly corrupt version, which also occurs in the Subhāșitaratnakaraṇdakakatha $\bar{a}^{14}$ :
lakșminniketaṃ yadapāśrayeṇa prāpto 'si lokābhimatam nụpatvaṃ
tāny eva punyāni vivardhayethā na karșaṇiyo hy upakāripakṣah
You should increase the very same religious merits, on the basis of which you have ob- tained the royalty respected by the people, which is the abode of [royal] fortune, as the supporters [i.e., the merits] are not to be weakened. ${ }^{15}$

After the eighth century, the patronage in favor of Buddhist monasteries apparently declined in western India. But this decrease does not seem to have been caused by the first, short-term Muslim inroads into Gujarat and Maharashtra in the early eighth century; in fact, the Hindu-Brahmanical endowment culture continued to prosper. The last extant Buddhist grants of the Maitraka kings date from around $675 \mathrm{CE},{ }^{16}$ while donations to Brahmins continued to be made until the end of the Maitraka rule (that is, until 765 or $766 \mathrm{CE}) .^{17}$ Maitraka grants to Hindu temples seem to have ceased even earlier, shortly after $640 \mathrm{CE}$, when

10 On the Buddhist endowments in general, see Shastri 2000: 417-452; for the mahāyānikavihāra as a grantee, see Bhandarkar 1872.

11 Bühler 1880; Banerji 1931-32; Parikh / Shelat 2000; Jackson 1898.

12 Bühler 1876: lines 13-14; Bühler 1877: line 30; Acharya 1925.

13 Kern 1943: 166, stanza 25.28.

14 Mirashi 1961. This is stanza 1.6: lakșminiketam yadupaśrayeṇa prāpto 'si lokābhimatam prabhutvam / tāny eva puṇyāni vivardhayetha na karṣaṇiyo hy upakāripakṣah; Hahn 1983: 331-332.

15 Speyer (1971 [1895]: 233) translated this stanza as: "It is by pursuing meritorious actions that thou obtainedst the royal dignity, a thing highly esteemed by men and the abode of bliss. That very store of merit you must enlarge, thou shouldst not enfeeble the ranks of the benefactors." The stanza was translated by Mirashi (1961) as: "The religious merit by virtue of which you have obtained [this] lordship respected in the world, which is the abode of royal fortune, should be augmented; the obliging ally [i.e., your religious merit] should not be harmed."

16 For the last dated Maitraka endowment to a Buddhist monastery, see Diskalkar 1925: 57-63, no. 18.

17 For the last dated copper-plate charter of the Maitrakas, a Brahmanical grant, see Fleet 1888. 
the Buddhist endowment culture still flourished. There are vague references to disturbances in a Buddhist nunnery at the beginning of the seventh century: One Maitraka copper plate inscription which records the renewal of an older grant (the original charter being lost), mentions that a certain convent no longer existed and that the nuns had moved to the Yakșaśūravihāra in Valabhī. ${ }^{18}$ But the reasons for this change could have been manifold, and the date was too early for any Muslim involvement. Although in the eighth century, the Maitraka kings no longer made grants to Buddhist monasteries, one eighth-century endowment record of the Saindhava king Ahivarman to a Buddhist nunnery in western Kathiawar has been preserved: a copper plate charter from Ambalasa in the Junagadh District ${ }^{19}$ was found together with two Maitraka title deeds in favor of monasteries for monks, which date from the early sixth and early seventh centuries, respectively. ${ }^{20}$

By contrast, there is some evidence that internal reasons may have contributed to a decrease in royal patronage of Buddhism. This is clear from a comparison of the Buddhist and the Brahmanical endowments of the Maitrakas. The early sixth-century grants were called brahmadāya; later, from the end of the sixth century onward, donations to Brahmins were mostly labeled with the more general term dharmadāya ('religious gift'); this last usage was probably influenced by the terminology used in Buddhist endowments. While these Brahmanical grants were formally "bestowed as dharmadāya," it is stated that they ought to be utilized "according to the proper condition of a brahmadāya." A complete phrase of this kind might read, for example,

Therefore not even a slight hindrance should be made or [any] objection [be raised] by anyone against the one [i.e., the Brahmanical donee] who is, according to the proper condition of a gift in favor of a Brahmin, enjoying [the land/village], cultivating [it], having [it] cultivated, or assigning [it to others for cultivation].

(yato 'syocitayā brahmadāyasthityā bhuñjatah kṛ̣atah karșayatah pradiśato vā na kaiścit svalpāpy ābādhā vicāraṇā vā kāryāa). ${ }^{21}$

This regulation entitled the recipient to simple usufruct as well as to - at least de iure - more complex usages of the object donated. In particular, when plots of arable land were singled out and then bestowed, the stipulation can be seen as even more important, because it permitted the beneficiaries to carry out different degrees of agricultural activity.

18 Gadre 1934: line 22.

19 Shastri / Dholakia 1969-70a.

20 Shastri / Dholakia 1969-70b; Shastri / Dholakia 1970-71.

21 See e.g., Sukthankar 1919-20: lines 19-20. 
A similarly complex equivalent was also used in some Buddhist endowments of the Maitraka rulers, for example,

Therefore, no impairment should be caused by anyone against the one [i.e., the order of monks] who is, according to the proper condition for the noble orders of Buddhist monks, enjoying [the villages], cultivating [them], or having [them] cultivated.

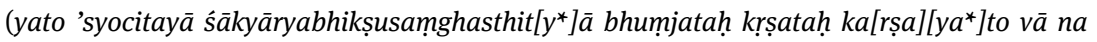
[kai]ścit pratiședhe vartitavyam). ${ }^{22}$

But often the formula was altered - perhaps after a request by monastic clergy for an appropriate Buddhist adaptation. Such a modified phrase reads, for example,

Therefore, no impairment should be made or [any] objection [be raised] by anyone against those appointed there, who are having what grows there collected.

(yatah tatrādhikṛtānām yat tatrotpadyate tad udgrāhayatām na kenacit pratiședho vicāranā vā kāryā) ${ }^{23}$

Under the king Siilāditya I, a particular formula, stressing the rather passive approach of Buddhist beneficiaries, was used:

And therefore, [the endowment,] being enjoyed according to the proper condition of a rent-free holding in favour of a deity, ${ }^{24}$ shall not be obstructed by anyone.

(yata ucitayā ca devāgrāhārasthityā bhujyamānakaḥ na kaiścit paripanthanīyaḥ). ${ }^{25}$

In comparison to Brahmanical endowments, this somewhat ambiguous handling of the prescriptions in Maitraka grants to vihäras may be explained by the Buddhists' generally strict attitude toward agriculture and their lack of interest in getting involved in farming. The Chinese pilgrim Yijing, who visited eastern India in the second half of the seventh century, reports:

When I for the first time visited Tāmralipti, I saw in a square outside the monastery some of its tenants who, having entered there, divided some vegetables into three portions, and having presented one of the three to the priests, retired from thence, taking the other portions with them... The priests in this monastery are mostly observers of the precepts. As cultivation by the priests themselves is prohibited by the great Sage, they suffer their taxable lands to be cultivated by others freely, and partake of only a portion of the

22 Bühler 1875b: lines 12-13.

23 Bühler 1875a: lines 23-25.

24 The term devāgrāhāra seems to denote grants for collective religious bodies. For agrahāra/ agrāhāra, see Sircar 1966: 10-11.

25 See e.g., Kielhorn 1885: line 29. 
products. Thus they live their just life, avoiding worldly affairs, and free from the faults of destroying lives by ploughing and watering fields. ${ }^{26}$

However, opinions on how to cope with this dogmatic problem (related to the undesirable nature of involvement in agriculture) seem to have differed (from region to region), for Yijing also says:

According to the teaching of the Vinaya, when a cornfield is cultivated by the Sangha (the Brotherhood or community), a share in the product is to be given to the monastic servants or some other families by whom the actual tilling has been done. Every product should be divided into six parts, and one-sixth should be levied by the Sangha; the Sangha has to provide the bulls as well as the ground for cultivation, while the Sangha is responsible for nothing else. Sometimes the division of the product should be modified according to the seasons.

Most of the monasteries in the West [i.e., India] follow the above custom, but there are some who are very avaricious and do not divide the produce, but the priests themselves give out the work to the servants, male and female, and see that the farming is properly done. ${ }^{27}$

In many parts of India, a certain decline in Buddhist donations by royal figures can be observed during the early medieval period. Inversely, Brahmins (and later, increasingly, Hindu temples) were favored on an even larger scale. As mentioned, one reason for this development might have been the comparative lack of interest the Buddhist monasteries showed in the village life; their traditional base in India was in towns and cities rather than the countryside. Brahmins, by contrast, seem to have fulfilled the 'expectations' of the kings and shaped the rural landscape much better - quite a number of them were personally active in agricultural activities, particularly those that received small, individual plots of land, not whole villages.

In terms of the political and military events in western India in the first half of the eighth century, Sind was conquered by the Arab forces in $711 \mathrm{CE}$, and according to Muslim sources, the first mosques were built in that region in the eighth century. ${ }^{28}$ In $736 \mathrm{CE}$, the Gurjara king Jayabhata IV, who ruled from Bharukaccha (Bharuch) in southeastern Gujarat and was a traditional rival of the Maitraka kings, was praised for beating the Tājikas (the Arabs) in or near Valabhī. ${ }^{29}$ A few years later, in 739 CE, the Tājikas reached Navasārikā, the

\footnotetext{
26 Takakusu 1982 [1896]: 62.

27 Takakusu 1982 [1896]: 61.

28 Wink 1990: 203.

29 See, for instance, Mirashi 1955: 85, no. 24, line 4; cf. also Virji 1952: 72-74. For the expression tājika as a term for 'Arab,' derived from the Middle Persian word tāzik, see Pingree 1981-82; Sundermann 1993.
} 
capital of the Lāta branch of the Cālukyas, some 90 kilometers south of Bharukaccha. ${ }^{30}$ But unlike the invasion of Sind (and Punjab), Arab inroads into Gujarat seem to have been limited, as the Cāhamāna Bhartrivaddha is known to have reigned from Bhṛukaccha (Bharukaccha/Bharuch) in $756 \mathrm{CE}$. According to his Hansot grant, ${ }^{31}$ Cāhamāna Bhartṛvaddha acknowledged the suzerainty of a ruler named Nāgāvaloka, who can most likely be identified with Pratihāra Nāgabhața I, who ruled over parts of northern India from around 730 to $760 \mathrm{CE}$ and is said to have ousted the Arabs (mleccha) from Ujjayanī. ${ }^{32}$ The information on the contemporary events at Valabhī is not very clear. In or shortly after 766 CE, Kathiawar was invaded again, this time by Amru b. Jamāl of Sind, who probably ended Maitraka rule. ${ }^{33}$ During another Arab invasion in 776 CE, Valabhī is said to have been destroyed. ${ }^{34}$

Thus, the early eighth-century invasion of Valabhī by the Tājikas came half a century after the last extant Buddhist grants of the Maitrakas. Although Buddhist monasteries, especially those situated in Valabhī itself, may have been destroyed during these raids, the Maitrakas recovered from the attack, ruled for at least another fifty years, and continued to make endowments to Brahmanical grantees. In this context it is striking that copper plate charters do not seem to have been issued from the city of Valabhī after the year 705-706 $\mathrm{CE},{ }^{35}$ rather, all the later Maitraka grants were issued from military camps, mainly from Khețaka (Kheda). ${ }^{36}$ The donations recorded in these title deeds were also not related to Valabhì: this is true in regard to the donees and the land bestowed on them. In the seventh century, many of the Brahmanical grantees had lived in the Maitraka capital. ${ }^{37}$ The concentration of endowments to Buddhist monasteries based in and around Valabhī was apparently even higher than that of grants to Brahmins residing there. Many of the vihäras for

30 Mirashi 1955: 141, no. 30, line 33.

31 Konow 1913-14.

32 Majumdar 1925-26: 107.

33 Fleet 1888: 171; Majmudar 1960: 226.

34 Majmudar 1960: 227; Ahmad 1966. For another date, i.e., 788 CE, see Shastri 1989: 61; Shastri 2000: 90-91.

35 On the topic of the last extant attestation of Valabhī as a place of issue, see Shastri 1956. Approximately half of the charters from the Maitraka corpus were issued from Valabhī.

36 See e.g., Shastri 1967-68.

37 See e.g., Diskalkar 1925: 28-31, no. 7. But Brahmins from Valabhī still appear as beneficiaries in some ninth-century endowments of the Lāța branch of the Rāșțrakūṭas; cf. Salomon 1998: 284-296, no. 10; Sircar 1963-64. 
monks and all the convents for nuns were situated in the city of Valabhi. ${ }^{38}$ Thus, we can assume that the destruction in the Maitraka capital during one of the Arab invasions must have affected the Buddhists to a larger extent than the Brahmins. Unfortunately, thus far, major excavations have not been carried out at this site, mostly because it is still inhabited (or inhabited again); all past excavations were confined to some edges of the current settlement. ${ }^{39}$

As mentioned, endowments to Buddhist monasteries in Gujarat did not come to a complete end with the Maitrakas. An eighth-century Saindhava grant is known to have been issued to a nunnery in the Junagadh area. ${ }^{40}$ Two copper plate charters of the Lāta branch of the Rāșțrakūṭas in favour of a monastery for monks date from the late ninth century. ${ }^{41}$ We do not know the exact locations of these two title deeds, but interestingly enough, one mentions that the monastic order - the beneficiary of the donation - hailed from Sindhuvișaya. ${ }^{42}$ This information may be interpreted as an indication of the exodus of Buddhist monks from the Sind region.

Yet, there is also epigraphic evidence that Muslim nobles not only engaged in military campaigns toward India's west coast, but also acted as subordinate lords under the main Rāṣțrakūṭa line that reigned over Maharashtra, Gujarat, and large parts of Karnataka from the eighth to the tenth centuries. As vassals of these indigenous kings, some Arab leaders seem to have made endowments following the pattern set by the native Indian rulers. One of the most striking examples is the famous Chinchani charter of Tājika Madhumati Sugatipa from the Saka year $848^{43}$ (926 CE). This deed records a grant for a Hindu mațikā (a temple college) of the goddess Daśamī Bhagavatī. Endowments to Hindu temples were still relatively rare in western India in the tenth century, thus, it is quite remarkable that a Muslim donor made this endowment to support worship at this temple college.

The content of the Chinchani charter of Tājika Madhumati (i.e., Muhammad) and its form clearly reflect pre-Islamic Indian traditions. The epigraph is written in Sanskrit and engraved on a copper plate in the usual way.

38 The Duḍ̣āvihāra was a renowned monastic complex in Valabhī; see e.g., Bühler 1875a and 1875b. The Yakṣaśūravihāra was a Buddhist nunnery in Valabhī; see e.g., Gadre 1934.

39 For this general problem at many early medieval sites, see Kennet 2013.

40 Shastri / Dholakia 1969-70a.

41 Bhandarkar 1900-01; Altekar 1933-34. Some endowment deeds from the famous Buddhist monastic complex at Kanheri near Mumbai, recorded on stone, also date from the ninth century; see e.g., Kielhorn 1884.

42 Altekar 1933-34: 75, lines 53-54.

43 Sircar 1957-58. Madhumati's charter is the first of a series of five epigraphs jointly discovered at Chinchani. 
Its introductory stanza is dedicated to the Hindu goddess Pārvatī and the god Śiva. It begins with a genealogy of the Rāștrakūṭa overlords (stanzas 5-15) in classical Indian literary style $(k \bar{a} v y a)$, followed by a description of the Tãjika Madhumati (Rāșțrakuṭa Indra III’s vassal) (stanzas 16-20), who administered the province of Samyāna, north of present-day Mumbai. ${ }^{44}$ Then the record mentions a minister of Madhumati named Puvvaiya (stanza 21), and describes the Brahmin Annaiya, who founded the mațhikā in Samyāna as a friend of minister Puvvaiya (stanza 22). From the subsequent prose passage on the endowment to the mațhikā we learn that Tājika Madhumati acted on a request of Annaiya (here: Annamaiya) and after obtaining the consent of Indra III, his overlord. With the approval of the highest tax collector of Samyāna, a clerk composed the text of the copper plate charter by order of the Tājika, who, for his part, received instructions from Indra III. From all these details we can deduce that the Arab vassal was somehow sandwiched between various levels of the indigenous hierarchy. In order to grant the revenue from villages of the territory he administered, he had to ask for the formal permission from his Rāștrakūṭa overlord, and had to consult the officials responsible for tax collection. Furthermore, the Muslim Madhumati acted on the request of a Brahmin who was apparently well-connected to the court.

A particularly beautiful passage on the concept of religious merit (punya) appears in the stanzas on protecting the endowment and serves as a prominent illustration of the Hindu-Brahmanical spirit of the charter of Tājika Madhumati Sugatipa:

yas tv ajñānapațalāndhitadṛștir anilabalāhatasarittaramgabhaṃuram ț̣nāgralagnāvaśyāyānavasthiram karikalabhakarnāgralolạ̣ śrāntavihagagalacapalam prakupitabhujagajihvātaditkșaṇadișțạn naștạn pratikṣaṇam anavasthitam gatijī[vi]tam anālocya ihāmutra ca ya[ś]aḥsaukhanidānam dānāt punyasaṃcayam anādṛtyādrșțaphalānabhijño durmatir ācchindyād ācchidyamānaṃ vānumodeta sa paṃcabhir mahāpātakais sopapātakaiś ca samyukta $\left[h^{*}\right]$ syād $\left[/^{*}\right]^{45}$

But the one who, because his eyes are blind due to the veil of ignorance, does not understand that life, which is [determined] by destiny, is transient, short-lived, and instable, breakable like a wave in the river, moved by the force of the wind, perishable like the frost adhering to a blade of grass, fluttering like the tip of the ear of a young elephant, seesawing like the neck of a tired bird, ephemeral like the moment of the quick darting of an agitated snake; the one who does not take into consideration that the accumulation of merit through munificence causes fame and happiness in this world and in the hereafter; and the one who should, as a fool who does not recognise merit and guilt, take away the

44 Before the grant, the administration of Samyāna had been handed over to him by Rāșțrakūṭa Kṛṣna II, the grandfather of Indra III (stanza 17).

45 Sircar 1957-58: lines 45-50. 
endowment, or approve its seizure, shall be afflicted with the five great and the small offenses.

In many respects, Tājika Madhumati Sugatipa was a rare exception. Most of the Muslims coming to India, like the local converts to Islam, supported their religion (and only their religion). According to Arab sources, the first mosques were erected in Sind in the eighth century and on the west coast in the tenth century. ${ }^{46}$ Initially, the foundations of Islamic rulers were recorded in Sanskrit, ${ }^{47}$ and apparently, even as late as the sixteenth century, it was not at all unusual to register a Muslim endowment entirely in Sanskrit and with the traditional Indian terminology. A Sanskrit inscription of 'Ādil Shāh above the entrance portal of the Jāma Masjid in Burhanpur in Madhya Pradesh, dated 1590 CE, ends with the sentence: "This mosque was erected [by 'Ādil Shāh] for the protection of his religion" (masitir iyam nirmitā svadharmapālanārtham). ${ }^{48}$ But already, from the late twelfth century onward, it was more common to use Arabic and later also Persian..$^{49}$ With the growing Muslim influence in western India, the institution of Islamic endowments $(\text { waqf })^{50}$ was introduced as well, and for the first time, a clear term and concept of endowment appeared in the subcontinent. Unfortunately, the early phase of this development has not been well explored. But, for example, at the end of the twelfth century, the Ghūrid sultan Muhammad b. Sām is said to have granted a village as waqf to the Jāma Masjid of Multan (in present-day Pakistan). ${ }^{51}$

We have two inscriptions of Muslim endowments in Gujarat at the south coast of Kathiawar and related to the famous medieval Hindu site of Somanātha (Somnath) ${ }^{52}$ : a Sanskrit epigraph engraved on a stone now fixed in the wall of a temple at Veraval (a few kilometers to the west of Somnath), and an Arabic inscription on a slab now built into the facade of a mosque, also at Veraval, both dated $1264 \mathrm{CE} .{ }^{53}$ From the content, we can conclude that the Arabic inscription, which is two months later than its Sanskrit counterpart, is a shorter, altered

46 Wink 1990: 69, 203.

47 Salomon 1998: 150.

48 Salomon 1998: 305-307, no. 14; especially 307, line 6.

49 Salomon 1998: 105-107.

50 For this institution in general, see e.g., Peters et al. 2002: 59-60.

51 Kozlowski 1985: 22. Even in the Mughal period, the term waqf was not frequently used; Kozlowski 1995.

52 For a recent discussion of the material and the often highly politicized debates on Somnath, see Thapar 2004.

53 For the Sanskrit epigraph, see Hultzsch 1882; Sircar 1961. For the Arabic epigraph, see Desai 1961: 10-15, no. 4. 
version of the Sanskrit inscription. The two documents do not illustrate BuddhistMuslim, but rather Hindu-Muslim encounters in the field of endowments. The Sanskrit epigraph follows the pre-Islamic Indian tradition and convention of recording religious foundations and grants, with the necessary adaptations for the Muslim beneficiaries. It opens with an invocation and a stanza praising Viśvanātha, 'the lord of the universe,' which clearly refers to Allāh. ${ }^{54}$ The date is given in four eras: according to the Muslim Hijri calendar and according to three indigenous Indian reckonings of years. ${ }^{55}$ The donations documented in the inscription are historically contextualized through references to the reign of the Caulukya ruler Arjunadeva, to his regional governor of Kathiawar, and to the local administrative body (pañcakula) of Somanāthadevapattana. The king Arjunadeva is described as an adherent of god Umāpati (Śiva), and one of the members of the local body is portrayed as a teacher of the (Śaiva) Pāśupata doctrine. ${ }^{56}$ The grant portion of the Sanskrit inscription exemplifies possible patterns of interaction between Muslims and Hindus in Gujarat in the second half of the thirteenth century. The inscription records the construction of a mosque (mijigiti) and the endowment by an Arab shipowner (nākhū $[d \bar{a}])$ from Hormuz for the maintenance of the religious building (dharmasthāna). The grant consisted of some land, an oil mill, and two marketplaces (hațta), which had to be obtained from local Hindu community leaders before being transferred to the mosque for their new purpose. The income from the endowments was to be used for certain posts and services at the mijigiti; any surplus was to be sent to Mecca and Medina. ${ }^{57}$

The Arabic version makes it clear that the grant was regarded as a waqf, that is, as an endowment according to Islamic prescriptions, as it uses the verbal form waqafa to describe the Muslim donor's actions. ${ }^{58}$ In the words of Himanshu Prabha Ray, the importance of the inscription lies mainly in the fact that "[i]n keeping with the legal requirements of Islamic law the mosque was definable as a waqf (i.e., a charitable endowment) and trustees and beneficiaries had to be appointed. The Arabic version is thus crucial to an understanding

54 Sircar 1961: 141 and 146, lines 1-2.

55 Sircar 1961: 141 and 146, lines 2-4. The Indian eras are the Vikrama, Valabhī, and Siṃha.

56 Sircar 1961: 146-147, lines 4-9: ... ㅅ́si-umāpativaralabdhaprauḍhapratāpa ${ }^{\circ} \ldots$ paramapāśupatācārya ${ }^{\circ}$.

57 Sircar 1961. For discussions of this text, cf. Thapar 2004: 88-95; Patel 2008: 145-148; Ray 2015: 297-298. For a Junagadh inscription, which dates from 1286-87 CE and commemorates the erection of a mosque by a merchant who sent pilgrims to Mecca on ships, see Desai 1961: 18-19, no. 7; Jain 1990: 76; Shokoohy 2003: 18.

58 Desai 1961: 13-14, lines 16-17; Patel 2008: 149. 
of the establishment of the institution of waqf in western India." 59 However, despite its being much shorter, the Arabic inscription also contains information absent from the Sanskrit text, for example, the following prayer: "[M]ay God make it [i.e., the city of Somanātha] one of the cities of Islam and [banish] infidelity and idols." ${ }^{60}$ Phrases like this prove that there was another agenda related to the spread of the institution of waqf, a goal hidden from those (many) contemporary local residents who did not comprehend Arabic.

From the early thirteenth century, a clear disruption in the indigenous endowment culture is discernible in many parts of northern and central India. This disruption resulted in the disturbance of existing grants, which had been made 'for eternity,' and in the decrease of new donations. As the large majority of the early medieval endowments consisted of royal revenues allocated to religious recipients, this disruption does not come as a surprise. The continuation of such grants could only be guaranteed by the rulers. But Muslim potentates are said to have often confiscated land and other sources of income that had been bestowed on monasteries and temples, ${ }^{61}$ probably to increase the taxable income of the state (like the British did later $)^{62}$ and perhaps also in order to patronize the waqf culture in India. Confiscations occasionally occurred in the pre-Islamic period as well. However, with the spread of Islamic rule, the consensus about the potential meritoriousness of Buddhist, Hindu-Brahmanical, and Jain endowments was lost. But while, over the course of time, Buddhist endowments entirely ceased, the tradition of Hindu and Jain endowments continued, although on a much smaller scale than before and mostly carried on by private individuals. ${ }^{63}$

\section{Bibliography}

Acharya, Girjashankar Vallabhaji (1925): “Notes on Some Unpublished Valabhī Copper-Plates Belonging to the Bombay Branch of the Royal Asiatic Society and Lent to the Prince of Wales Museum of Western India: No. II. - Plates of Dharasena II, dated [Gupta-]Samvat 270." Journal of the Bombay Branch of the Royal Asiatic Society, N.S., 1: 66-69.

Ahmad, N. (1966): "A Fresh Estimate of Early Arab Invasions of India." Journal of the Oriental Institute of Baroda 16.2: 183-187.

59 Ray 2015: 298. For the implications of this, see also Patel 2008: 155-156.

60 Desai 1961: 14, lines 6-7. For this attitude toward kufr and așnām, see also Patel 2008: 148. 61 For exaggerations of the amount of Hindu endowments in Muslim sources, see Thapar 2004: 57.

62 For the early British attitude toward Hindu endowments, see Orr 2011: 154. On waqf, see Kozlowski 1987.

63 Orr 2011: 153. 
Altekar, A. S. (1933-34): "A New Copper-Plate of Dhruva II of the Gujarat Rashtrakuta Branch, dated Saka 806." Epigraphia Indica 22: 64-76.

Banerji, R. D. (1931-32): “The Bhadreniyaka Grant of Siladitya I; G.E. 292.” Epigraphia Indica 21: 116-119.

Bhadkamkar, H. M. (1911-12): “Navalakhi Plates of Siladitya I. - [Gupta-] Samvat 286.” Epigraphia Indica 11: 174-180.

Bhandarkar, Devadatta Ramakrishna (1900-01): “Plates of Dantivarman of Gujarat; SakaSamvat 789.” Epigraphia Indica 6: 285-294.

Bhandarkar, Ramkrishna Gopal (1872): “On Two Copperplates from Valabhi: Plate I.” The Indian Antiquary 1: 45-46.

Borgolte, Michael (2014): “Introduction.” In: Enzyklopädie des Stiftungswesens in mittelalterlichen Gesellschaften. Vol. 1: Grundlagen. Edited by Michael Borgolte. Berlin: De Gruyter, 14-18.

Bühler, Georg (1875a): “A Grant of King Dhruvasena I. of Valabhī.” The Indian Antiquary 4: 104-107.

Bühler, Georg (1875b): “A Grant of King Guhasena of Valabhī.” The Indian Antiquary 4: 174-176.

Bühler, Georg (1876): “Grants from Valabhī: B. - The Grant of Guhasena.” The Indian Antiquary 5: 206-207.

Bühler, Georg (1877): “Further Valabhī Grants: A. - The Grant of Dharasena I [sic!].’ The Indian Antiquary 6: 9-12.

Bühler, Georg (1880): “Valabhī Grants: No. XV. - A Grant of Śīāditya I., dated Samvat 290.” The Indian Antiquary 9: 237-239.

Desai, Z. A., (1961): “Arabic Inscriptions of the Rajput Period from Gujarat.” Epigraphia Indica. Arabic and Persian Supplement: 1-24.

Diskalkar, D. B. (1925): "Some Unpublished Copper-Plates of the Rulers of Valabhī." Journal of the Bombay Branch of the Royal Asiatic Society, N.S., 1: 16-63.

Fleet, John Faithful (1888): “Alina Copper-Plate Inscription of Siladitya VII. The Year 447." In: Inscriptions of the Early Gupta Kings and Their Successors (Corpus Inscriptionum Indicarum; 3). Calcutta: Office of the Superintendent of Government Print, 171-191.

Gadre, A. S. (1934): "Five Vala Copper-Plate Grants: Grant No. II. Copper-plate Grant of Śīāditya (I) alias Dharmāditya of the Gupta Saṃvat 287 (606 A.D.).” Journal of the University of Bombay 3: 80-82.

Hahn, Michael (1983): “Die Subhāṣitaratnakaraṇḍakakathā. Ein spätbuddhistischer Text zur Verdienstlehre." Nachrichten der Akademie der Wissenschaften in Göttingen.

I. Philologisch-Historische Klasse 9, Jahrgang 1982: 320-374.

Heim, Maria (2004): Theories of the Gift in South Asia. Hindu, Buddhist, and Jain Reflections on Dāna. New York: Routledge.

Hinüber, Oskar von (2013): "Behind the Scenes: The Struggle of Political Groups for Influence as Reflected in Inscriptions." Indo-Iranian Journal 56: 365-379.

Hultzsch, Eugen (1882): “A Grant of Arjunadeva of Gujarat.” The Indian Antiquary 11: 241-245. Jackson, A. M. T. (1898): “Two New Valabhī Copper-plates.” Journal of the Bombay Branch of the Royal Asiatic Society 20: 1-6.

Jain, V. K. (1990): Trade and Traders in Western India (AD 1000-1300). Delhi: Munshiram Manoharlal.

Kane, Pandurang Vaman (1941): History of Dharmaśāstra (Ancient and Medieval Religious and Civil Law in India). Vol. 2.2. Poona: Bhandarkar Oriental Research Institute. 
Kennet, Derek (2013): “Reconsidering the Decline of Urbanism in Late Early Historic and Early Medieval South India." In: Les preludes de l'Islam. Ruptures et continuities dans les civilisations du Proche-Orient, de l'Afrique, de l'Arabie et de l'Inde à la veille de l'Islam. Edited by C. J. Robin and J. Schiettecatte. Paris: De Boccard, 331-351.

Kern, Hendrik (ed.) (1943): The Jātakamālā. Stories of the Buddha's Former Incarnations. Otherwise Entitled Bodhisattva-Avadāna-Mālā by Ārya-Śūra. Critically Edited in the Original Sanskrit. Cambridge, MA: Harvard University Press.

Kielhorn, Franz (1884): “Three Inscriptions from Kanheri.” The Indian Antiquary 13: 133-137.

Kielhorn, Franz (1885): “A Copper-Plate Grant of Siladitya I. of Valabhi.” The Indian Antiquary 14: 327-330.

Konow, Sten (1913-14): “Hansot Plates of the Chahamana Bhartrivaddha; Samvat 813." Epigraphia Indica 12: 197-204.

Kozlowski, Gregory C. (1985): Muslim Endowments and Society in British India. Cambridge: Cambridge University Press.

Kozlowski, Gregory C. (1987): "Muslim Women and the Control of Property in North India." Indian Economic and Social History Review 24.2: 163-181.

Kozlowski, Gregory C. (1995): "Imperial Authority, Benefactions and Endowments (Awqaf) in Mughal India." Journal of the Economic and Social History of the Orient 38.3: 355-370.

Majmudar, M. R. (1960): Historical and Cultural Chronology of Gujarat (from Earliest Times to End of Rāșțrakūṭa-Pratīhāra Period, i.e. up to 942 A.D.). Baroda: Maharaja Sayajirao University of Baroda.

Majumdar, R. C. (1925/26): “The Gwalior Prasasti of the Gurjara-Pratihara King Bhoja.” Epigraphia Indica 18: 99-114.

Mirashi, Vasudev Vishnu (ed.) (1955): Inscriptions of the Kalachuri-Chedi Era (Corpus Inscriptionum Indicarum; 4). Vol. 1. Ootacamund: Gov. Epigraphist for India.

Mirashi, Vasudev Vishnu (1961): “A Note on the Subhāṣitaratnakaraṇḍakakathā of Āryaśūra.” Adyar Library Bulletin 25: 304-307.

Orr, Leslie (2011): “Religious Endowments and Gift Giving.” In: Brill’s Encyclopedia of Hinduism. Vol. 3: Society, Religious Specialists, Religious Traditions, Philosophy. Edited by Knut A. Jacobson et al. Leiden: Brill, 151-155.

Pargiter, F. E. (1912): "Verses Relating to Gifts of Land Cited in Indian Land Grants." Journal of the Royal Asiatic Society, N. S., 44.1: 248-254.

Parikh, P. C. / Shelat, Bharati (2000): "Kukad Copper-plate Grant of Maitraka King Dhruvasena I, Valabhi Samvat 206." In: Gleanings of Indian Archaeology, History and Culture, in Honour of Prof. R.N. Mehta. Vol. 1. Edited by K. D. Bajpai. Jaipur: Publ. Scheme, 217-220. Patel, Alka (2008): “Transcending Religion.” In: Ancient India in Its Wider World. Edited by Grant Parker and Carla Sinopoli. Ann Arbor: University of Michigan Press, 143-164.

Peters, Rudolph et al. (2002): "Waḳf." In: Encyclopaedia of Islam. 2nd edition. Leiden: Brill, 11: 59-75.

Pingree, David (1981-82): "Sanskrit Evidence for the Presence of Arabs, Jews and Persians in Western India: Ca. 700-1300." Journal of the Oriental Institute Baroda 31.2: 172-182.

Ray, Himanshu Prabha (2015): "Trading Partners across the Indian Ocean: The Making of Maritime Communities." In: Expanding Webs of Exchange and Conflict, 500 CE-1500 CE (Cambridge World History; 5). Edited by Benjamin Z. Kedar and Merry E. Wiesner Hanks. Cambridge: Cambrige University Press, 287-308.

Salomon, Richard (1998): Indian Epigraphy. A Guide to the Study of Inscriptions in Sanskrit, Prakrit, and the Other Indo-Aryan Languages. New York: Oxford University Press. 
Schmiedchen, Annette (2014): Herrschergenealogie und religiöses Patronat. Die Inschriftenkultur der Rāșțrakūtas, Śilāhāras und Yādavas (8. bis 13. Jahrhundert). Leiden: Brill.

Schopen, Gregory ([1985] 1997): "Two Problems in the History of Indian Buddhism. The Layman/ Monk Distinction and the Doctrines of the Transference of Merit." In: Gregory Schopen, Bones, Stones, and Buddhist Monks. Collected Papers on the Archaeology, Epigraphy, and Texts of Monastic Buddhism in India. Honolulu: University of Hawai'i Press, 23-55.

Shastri, Hariprasad G. (1956): "Sihoramāṃthī malelum Valabhī rājyanuṃ eka aprasiddha tāmraśāsana.” Buddhiprakāśa 103: 9-14, 73-77, 102-105.

Shastri, Hariprasad, G. (1967/68): “The Text of the Two Copper-Edicts from Vadnagar: CopperEdict of Siilāditya V." Journal of the Oriental Institute of Baroda 17.2: 186-191.

Shastri, Hariprasad G. (1989): A Historical and Cultural Study of the Inscriptions of Gujarat from Earliest Times to the End of the Chaulukya Period (circa 1300 A.D.). Ahmedabad: B. J. Institute of Learning and Research.

Shastri, Hariprasad G. (2000): Gujarat under the Maitrakas of Valabhī. History and Culture of Gujarat during the Maitraka Period, ca. 470-788 A.D. Vadodara: Oriental Institute.

Shastri, Hariprasad G. / Dholakia, P. V. (1969-70a): "Ambalas Plates of the Saindhava King Ahivarman." Journal of the Oriental Institute of Baroda 19: 279-285.

Shastri, Hariprasad G. / Dholakia, P. V. (1969-70b): "Valabhīna Maitraka rājā Dhruvasena 1-Lānuṃ dānapatra.” Svādhyāya 7.2: 235-239.

Shastri, Hariprasad G. / Dholakia, P. V. (1970-71): "Maitrakarājā Śīlāditya 1-Lānuṃ Āmbalāsa dānapatra." Svādhyāya 8.1: 178-184.

Shokoohy, Mehrdad (2003): Muslim Architecture of South India: The Sultanate of Ma'bar and the Traditions of Maritime Settlers on the Malabar and Coromandel Coasts. London: Routledge Curzon.

Sircar, Dinesh Chandra (1957-58): "Rashtrakuta Charters from Chinchani: 1. Grant of the Time of Indra III, Śaka 848.” Epigraphia Indica 32: 45-55.

Sircar, Dinesh Chandra (1961-62): "Veraval Inscription of Chaulukya-Vaghela Arjuna, 1264 A.D.” Epigraphia Indica 34: 141-150.

Sircar, Dinesh Chandra (1963-64): “Devali Plates of Govinda, Valabhi 500.” Epigraphia Indica 35: 269-280.

Sircar, Dinesh Chandra (1966): Indian Epigraphical Glossary. Delhi: Motilal Banarsidass.

Speyer, J. S. ([1895] 1971): The Jātakamālā. Garland of Birth-Stories of Āryaśūra. Delhi: Motilal Banarsidass.

Sukthankar, V. S. (1919-20): “Bhavnagar Plates of Dhruvasena I: [Valabhi-]Samvat 210.” Epigraphia Indica 15: 255-258.

Sundermann, Werner (1993): “An Early Attestation of the Name of the Tajiks." In: Medioiranica. Proceedings of the International Colloquium Organized by the Katholieke Universiteit Leuven from the 21st to the 23rd May of May 1990. Edited by W. Skalmowski and A. van Tongerloo. Leuven, 163-171.

Takakusu, Junjiro ([1896] 1982): A Record of the Buddhist Religion as Practised in India and the Malay Archipelago (A.D. 671-695). Delhi: Manoharlal.

Thapar, Romila (2004): Somanatha: The Many Voices of a History. Delhi: Penguin.

Virji, Krishnakumari J. (1952): Ancient History of Saurashtra (Being a Study of the Maitrakas of Valabhi. V to VIII Centuries A.D.). Bombay: Konkan Institute of Arts and Sciences.

Wink, André (1990): Al-Hind: The Making of the Indo-Islamic World. Vol. 1: Early Medieval India and the Expansion of Islam 7th-11th Centuries. Leiden: Brill. 